Correcting calf girth discriminates the incidence of falling but not bone mass by broadband ultrasound attenuation in elderly female subjects.

STEWART, A.D., STEWART, A. and REID, D.M. 


\title{
Correcting Calf Girth Discriminates the Incidence of Falling But Not Bone Mass by Broadband Ultrasound Attenuation in Elderly Female Subjects
}

\author{
A. D. STEWART, ${ }_{1}$ A. STEWART,, 2 and D. M. REID 2 \\ ${ }_{1}$ Biomedical Sciences, University of Aberdeen, Aberdeen, UK \\ ${ }_{2}$ Osteoporosis Research Unit, Department of Medicine and Therapeutics, University of Aberdeen, Woolmanhill Hospital, Aberdeen, UK
}

\section{ABSTRACT}

Calf circumference has been cited as an independent risk factor for hip fracture. Correcting this measured girth for subcutaneous adipose tissue or fluid accumulation provides a more valid estimate of lean tissue, but has not been reported in elderly populations. Two hundred eighty-eight randomly selected female volunteers, aged $>70$ years, were assessed by quantitative ultrasound (QUS) and clinical risk factors as part of a larger screening study for hip fracture risk. This involved measuring broadband ultrasound attenuation (BUA) and administering a structured risk factor questionnaire that included estimated daily skeletal loading (time standing or walking). Body mass index (BMI) was estimated using current body mass and height at age 25 years. Calf girth was measured using a standard anthropometric tape, the medial calf skinfold (a vertical fold at the point of maximum calf girth) was measured, and corrected calf girth (CCG) was calculated by subtracting the skinfold (in centimeters) multiplied by pi from calf girth. Subjects were aged 76.9 plus/minus 5.0 years, had BMls of 24.3 plus $/$ minus $3.9 \mathrm{~kg} / \mathrm{m2}$, and spent an average of 5.5 plus/minus $2.0 \mathrm{~h}$ on their feet each day. Age, current body mass, BMI calf girth, and CCG all correlated with BUA $(p<0.01)$. CCG correlated with hours on the feet $(p<0.05)$, whereas calf girth did not $(p>0.05)$. Dividing the sample into tertiles by these correlates of BUA and predicting BUA using stepwise regression revealed different predictors for each tertile. Of the total sample, 93 had fallen in the last 12 months, whereas 195 had not. Independent t-tests showed these groups to be similar in age, BMI, and calf girth $(p>0.05)$, but fallers spent less time on their feet each day, and had smaller CCG $(p<0.05)$. This suggests that larger calf muscles may be protective against falling-possibly as a result of enhanced stability or greater neuromuscular control.

\section{KEY WORDS}

Corrected calf girth; Broadband ultrasound attenuation (BUA); Falling incidence; Skinfold; Anthropometry; Elderly females. 


\section{INTRODUCTION}

There are many influences on the skeletal morphology of healthy adults, including genetic, anthropometric, nutritional, and lifestyle factors. Between $78 \%$ and $92 \%$ of the variation in a subject's bone strength is attributable to bone mineral density as assessed by dual-energy X-ray absorptiometry (DXA).4 Broadband ultrasound attenuation (BUA) is a measure of the structural anisotropy of bone, which includes the elastic and strength components.7 This has been shown to be of clinical utility in assessing bone mass in subjects at risk of fracture,11 and predicts fractures, especially in the elderly.3,8,12 In elderly populations, $90 \%$ of hip fractures are attributed to a fall,13 and because the cost of treating fractures is now estimated at $£ 1.7$ billion in the UK,16 targeting high-risk groups for fracture within elderly populations is an important priority. Bone mass and the incidence of falling are among the many variables that could be used to target therapeutic intervention.

Although physical activity is considered to be protective against bone loss, 2 it is also difficult to quantify. Calf circumference has been cited as an independent risk factor for hip fracture. 5 This could be because it is a crude estimate of musculature, which may be considered to offer a convenient surrogate for physical activity measurement in this population, or an index of lean tissue, which could be protective in the event of a fall. However, it could be argued that differences in soft tissue composition (musculature, adipose tissue, and extracellular fluid) of the calf could have an influence over the validity of this measure. Corrected circumferences were first used to overcome this methodological problem in the early 20th century by subtracting skinfold thickness (assumed to represent twice the subcutaneous adipose tissue thickness) from girth.10 This approach is routinely used today in muscle mass estimation in other populations.9 Despite their convenience, such simple anthropometric measurements have not been implemented in the elderly. The aim of this study was to assess the value of correcting the total calf measurement for skinfold thickness and correlating both corrected and uncorrected values with BUA, thereby providing a measure of bone mass that is less dependent upon adiposity.

\section{SUBJECTS AND METHODS}

Two hundred eighty-eight female volunteers, aged greater than or equal to 70 years, resident in the Aberdeen area were randomly selected and measured for BUA as part of a larger screening study for hip fracture risk. This involved measuring BUA using a McCue CUBA Clinical Mark II portable quantitative ultrasound scanner (Mc- Cue, Hampshire, UK) and administered a structured questionnaire to estimate fracture risk. This included an estimate of the number of hours each day the subject was loading the skeleton in an upright manner (i.e., standing or walking) during a typical day. Body mass index (BMI) was estimated from current body mass and maximal height (estimated at age 25 years). With the subject seated, calf circumference was measured using a standard anthropometric tape, and medial calf skinfold was recorded by means of a vertical fold at the point of maximum circumference using Harpenden calipers (British Indicators, Luton, UK). Medial calf skinfold had been previously measured for precision using the same calipers and technique at $2.5 \%$ technical error of measurement.15 Following the standard procedure, 9 corrected calf girth (CCG) was calculated by subtracting pi multiplied by the skinfold (in centimeters) from the total calf measurement. This methodology is illustrated schematically in Figure 1 . The data were analyzed using independent t-tests, simple regression analysis, forward stepwise regression modeling, and one-way analysis of variance (ANOVA) with Student-Newman-Keuls post hoc tests to identify homogeneous subsets, using SPSS version 9.0. $p<0.05$ was considered statistically significant. Written, informed consent was obtained, and the study was approved by the Grampian Research Ethics Committee. 


\section{RESULTS}

Anthropometric variables and measurement results are summarized in Table 1. The relationship between BUA and the measured variables was examined to establish if simple morphological measurements showed any relationship with BUA. Correlations are summarized in Table 2.

Regression analysis was used to establish which factors best predicted BUA. When the aforementioned variables were entered into a stepwise regression analysis, only body mass and age and were significant predictors in the following equation:

$$
\begin{aligned}
\mathrm{BUA} & =32.8+0.366 \text { (mass) }-0.381 \text { (age) } \\
r 2 & =0.11 ; \mathrm{SEE}=13.8 ; \mathrm{p}<0.001
\end{aligned}
$$

Corrected calf girth showed a significant correlation with hours on the feet per day $(r=0.05, p-0.033)$, whereas calf girth did not $(r=0.05, p-0.394)$.

Data were grouped into tertiles according to age, body mass, BMI, calf girth, and CCG to establish whether BUA exhibited a gradient across anthropometric measurements. One-way ANOVA and Student-NewmanKeuls post hoc tests determined if there were differences in BUA between the groups. There were differences in BUA when the entire group was subdivided by mass, calf girth and CCG $(p<0.001)$, age, and BMI ( $p<0.01$ ), but not hours of exercise (not significant [n.s.], $p=0.90$ ). Correlation coefficients between the variables were compared for each tertile. Significant correlates with BUA are summarized in Table 3.

Of the total sample, a total of 93 subjects had fallen in the past 12 months, whereas 195 had not. A comparison of these groups is provided in Table 4.

Independent t-tests indicated that these two groups did not differ in terms of age, body mass, BMI, and calf girth ( $p>0.05)$, but fallers spent less time on their feet each day, and had lesser CCG $(p<0.05)$.

\section{DISCUSSION}

Although this study found that BUA is most strongly related to body mass and age, calf girth and CCG both showed a significant correlation with BUA $(p<0.01)$. However, neither calf parameter was selected as a predictor of BUA in the stepwise regression analysis. On the other hand, increased risk of falling was best indicated by reduced CCG and hours per day on the feet.

Bone mass usually peaks in the third decade and declines thereafter, and this effect is more marked after menopause. 2 During later life, physical activity of a weight-bearing nature is considered protective against bone loss, whereas weight-supported activities such as swimming or cycling have little or no effect.1 Although these activities might have no effect on bone, they could influence muscle development in terms of improving neurological pathways or retarding sarcopenia.14 As a result, these factors may confound the ability of calf measurements to predict bone. Furthermore, calf muscle morphology may be influenced by other factors, such as body build, walking activity (distance and gait), footwear design, etc. Although bone mass by BUA was best predicted from body mass and age, there was no relationship between hours on the feet per day and total mass $(p>0.05)$. This may be plausible if, compared with lighter subjects heavier individuals induce greater bone strain when weight bearing, and adjustment of bone architecture is largely a consequence of strain magnitude, but not strain frequency or duration. 6

One weakness in the present study is that calf strength was not measured. It is possible that muscle bulk may be influenced by different types of exercise, which utilize different components of strength and endurance. Despite an in-depth interview of lifestyle, strength activities may be hard to quantify in 
subjects - but would include for instance one individual who was a regular downhill skier and another who habitually ascended and descended stairs two at a time. If the greatest component of physical activity in this sample is walking-based, then strength becomes less of a concern. Because our population of women were aged 70-98 years, downhill skiing and taking the stairs two at a time are unlikely to be common activities. However, skeletal loading may be influenced more by static standing weightbearing activity rather than ambulatory effort, with individuals having greater body weight exerting greater loading forces.

Data from dividing the sample into tertiles by age, mass, BMI, calf girth, and CCG suggest that variability in bone as measured by BUA may be more complex than first imagined. On the one hand, for no variable are the predictor variables of BUA the same for each tertile group, which suggests that influence of the variables may affect different portions of the total sample.

Rather than informing the study of bone and hip fracture risk in elderly subjects, the contribution of calf measurement lies predominantly in preventing falls, which remain a leading cause of fracture. The significance of CCG measurement difference between fallers and nonfallers, despite no age, body mass, or calf differences, supports the theory that larger corrected calf measurements are associated with better stability. The skinfold methodology is crude and, in addition to adipose tissue, extracellular fluid could enlarge the caliper measurements. Although this may threaten the validity of predicting fat content, it is less critical in the prediction of corrected girth.

In summary, both body mass and age are significant predictors of BUA, and correcting for calf adipose tissue offers no benefit in improving the accuracy of this prediction. The questionnaire results suggest that hours on the feet per day, and direct measurements of corrected calf girth, confirm a significant difference between those subjects who have fallen within the last 12 months and those who have not. Hours on the feet may appear to be an attractive measure due to its simplicity, but it is cumbersome to verify without recourse to obtaining accelerometer or other data on mechanical loading. By comparison, caliper measurements that enable corrected calf girth data to be collected are straightforward, inexpensive, and convenient, and such a methodology could prove useful as a diagnostic tool in future studies of fracture risk in elderly populations.

\section{ACKNOWLEDGEMENTS}

The authors are grateful to the Arthritis Research Council for personal funding for A.S. and continued infrastructure funding (D.M.R.). This work was carried out as part of a study funded by Research into Ageing.

\section{REFERENCES}

1. American College of Sports Medicine. Position stand on osteoporosis and exercise. Med Sci Sports Exerc 27:i-vii; 1995.

2. Bailey, D. A. and McCulloch, R. G. Bone tissue and physical activity. Can J Sport Sci 15:229-239; 1990.

3. Bauer, D. C., Gluer, C. C., Cauley, J. A., Vogt, T. M., Ensrud, K. E., Genant, H. K., and Black, D. M. Broadband ultrasound attenuation predicts fractures strongly and independently of densitometry in older women. Arch Intern Med 157:629-634; 1997.

4. Bouxsein, M. L., Coan, B. S., and Lee, S. C. Prediction of the strength of the elderly proximal femur by bone mineral density and quantitative ultrasound measurements of the heel and tibia. Bone 25:49-54; 1999. 
5. Darjent-Molina, P., Favier, F., Grandjean, H., Baudoin, C., Schott, A. M., Hausherr, E., Meunier, P. J., and Breart, G. Fall-related factors and risk of hip fracture: The EPIDOS prospective study. Lancet 348:145-149; 1996.

6. Frost, $\mathrm{H}$. Why do marathon runners have less bone than weight lifters? A vital biomechanical view and explanation. Bone 20:183-189; 1997.

7. Gluer, C. C., Wu, C. Y., Jergas, M., Goldstein, S. A., and Genant, H. K. Three quantitative ultrasound parameters reflect bone structure. Calcif Tissue Int 55:46-52; 1994.

8. Hans, D., Dargent-Molina, P., Schott, A. M., Serbert, J. L., Cormier, C., Kotzki, P. O., Delmas, D., Pouilles, J. M., Breart, G., and Meunier, P. J. Ultrasonographic heal measurements to predict hip fracture in elderly women: The EPIDOS prospective study. Lancet 348:511-514; 1996.

9. Martin, A. D., Spenst, L. F., Drinkwater, D. T., and Clarys, J. P. Anthropometric estimation of muscle mass in men. Med Sci Sports Exerc 22:729-733; 1990.

10. Mateigka, J. The testing of physical efficiency. Am J Phys Anthropol 4:223-230; 1921.

11. Nevitt, M. C. and Cummings, S. R. Falls and fractures in older women. In: Vellas, B., Toupet, M., Rubenstein, L., et al., Eds. Falls, Balance and Gait disorders in the Elderly, Paris: Elsevier; 1992: 69-80.

12. Porter, R. W., Miller, C. G., Grainger, D., and Palmer, S. B. Prediction of hip fracture in elderly women: A positive study. Br Med J 301:638-641; 1990.

13. Reid, D. M. and Stewart, A. Quantitative ultrasound-clinical utility. In: Ring, E. F. J., Elvins, D. M., and Bahalla, A. K., eds. Current Research in Osteoporosis and Bone Mineral Measurement V. London: British Institute of Radiology; 57-59; 1998.

14. Spirduso, W. W. Physical Dimensions of Aging. Champaign IL: Human Kinetics; 1995 123-151.

15. Stewart, A. D. and Hannan, W. J. Body composition prediction in male athletes using dual X-ray absorptiometry as the reference method. J Sports Sci 18:263-274; 2000.

16. Torgerson, D. J., Iglesias, C. P. Reid, D. M. The economics of fracture prevention. In: Barlow, D. H., Francis, R. M., Miles, A. Eds. The Effective Management of Osteoporosis UK Advances in Clinical Practice Series. London: Aesulapius: 2001; 111-121. 
FIGURES

FIGURE 1. Schematic cross section of calf, showing skinfold measurement. Corrected girth assumptions: (1) The leg can be represented by a concentric tissue model with a circular cross section. (2) Limb muscle girth = limb girth $-2 \pi d$, where $d$ is the depth of adipose tissue plus skin. (3) The skinfold reading s is twice the adipose tissue depth, and thus limb muscle girth = limb girth - $\pi$ s. Methodology from reference 9 .

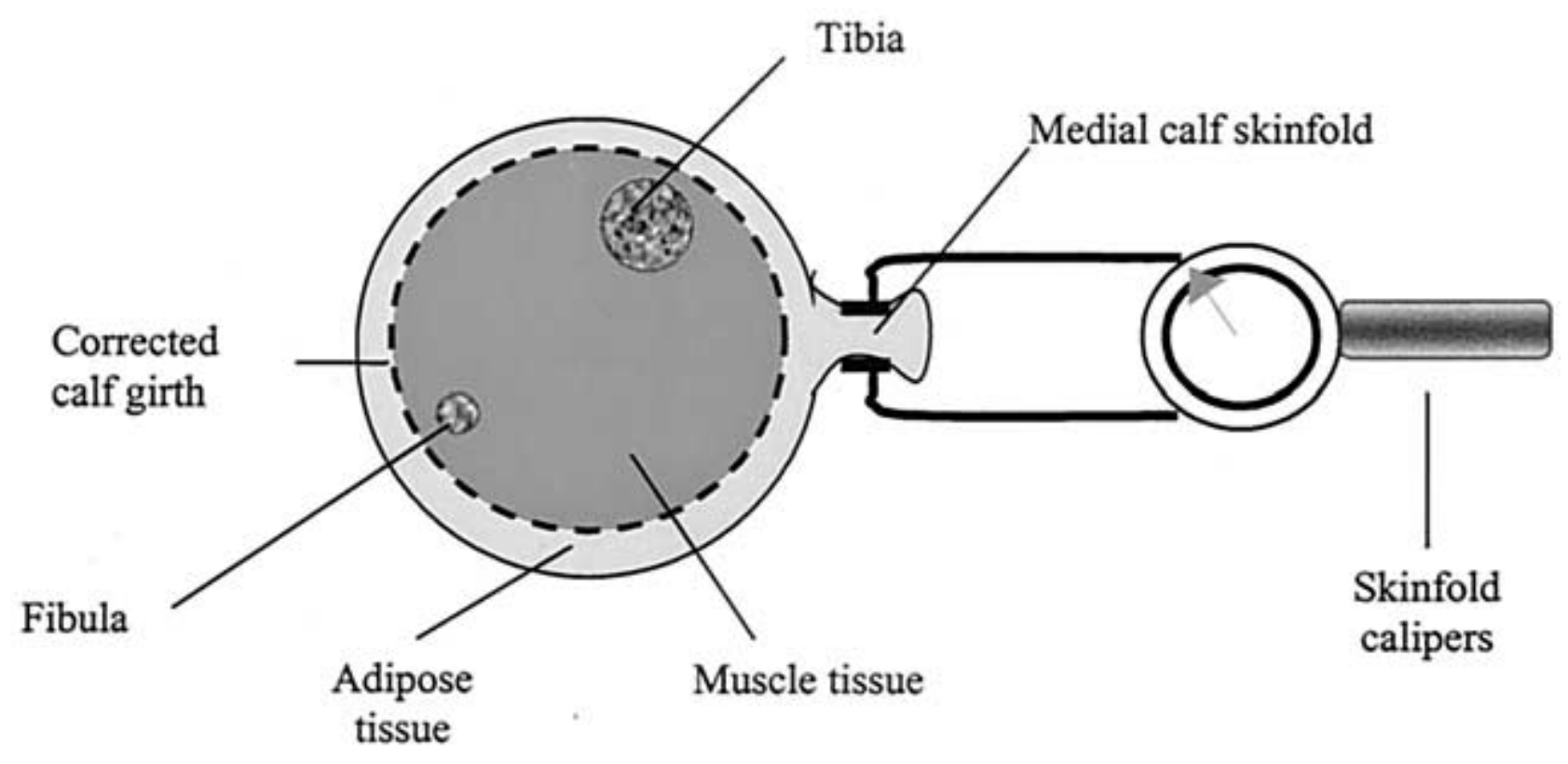

TABLES

TABLE 1. Physical and anthropometric characteristics of subjects

\begin{tabular}{|l|l|l|l|l|}
\hline Variable & Mean & SD & Min. & Max. \\
\hline Age (years) & 76.9 & 5.0 & 70.0 & 98.4 \\
\hline Total body mass $(\mathrm{kg})$ & 62.0 & 11.0 & 41.0 & 112.4 \\
\hline Body mass index $\left(\mathrm{kg} / \mathrm{m}^{2}\right)$ & 24.3 & 3.9 & 16.3 & 43.9 \\
\hline Hours per day on feet & 5.5 & 2.0 & 1.0 & 12.0 \\
\hline Calf girth (cm) & 34.4 & 3.5 & 26.0 & 55.0 \\
\hline Medial calf skinfold $(\mathrm{mm})$ & 17.2 & 6.2 & 4.6 & 38.0 \\
\hline Corrected calf girth $(\mathrm{cm})$ & 29.0 & 2.7 & 23.0 & 50.6 \\
\hline BUA (dB/MHz) & 58.7 & 14.5 & 19.0 & 105.0 \\
\hline BUA, broadband ultrasound attenuation & & & \\
\hline
\end{tabular}


TABLE 2. Correlation of physical variables with broadband ultrasound attenuation (BUA) across entire sample $(N=288)$

\begin{tabular}{|l|l|}
\hline Variable & $\mathbf{r}$ \\
\hline Age (years) & $-0.22^{\mathrm{a}}$ \\
\hline Hours per day on feet & 0.07 \\
\hline Total body mass $(\mathrm{kg})$ & $0.22^{\mathrm{a}}$ \\
\hline Body mass index $\left(\mathrm{kg} / \mathrm{m}^{2}\right)$ & $0.27^{\mathrm{a}}$ \\
\hline Calf girth $(\mathrm{cm})$ & $0.28^{\mathrm{a}}$ \\
\hline Corrected calf girth $(\mathrm{cm})$ & $0.26^{\mathrm{a}}$ \\
\hline${ }^{a}$ Correlation significant at $p<0.01$. & \\
\hline
\end{tabular}

TABLE 3. Significant correlation with BUA with sample divided into tertile groups

\begin{tabular}{|c|c|c|c|}
\hline Tertile variable groups according to: & Lowest tertile & Middle tertile & Highest tertile \\
\hline Age (years) & n.s. & $\begin{array}{l}\text { BMI } 0.34^{b} \\
\text { Calf } 0.44^{b} \\
\text { CCG } 0.46^{b} \\
\text { Mass } 0.38^{b}\end{array}$ & $\begin{array}{l}\text { BMI } 0.25^{\mathrm{a}} \\
\text { Calf } 0.27^{\mathrm{a}} \\
\text { Mass } 0.29^{\mathrm{a}}\end{array}$ \\
\hline Total body mass (kg) & $\begin{array}{l}\text { Age }-0.32^{b} \\
\text { BMI } 0.27^{\mathrm{a}} \\
\text { Calf } 0.32^{\mathrm{b}} \\
\text { CCG } 0.24^{\mathrm{a}} \\
\text { Mass } 0.21^{\mathrm{a}}\end{array}$ & n.s. & CCG $0.21^{\mathrm{a}}$ \\
\hline $\mathrm{BMI}\left(\mathrm{kg} / \mathrm{m}^{2}\right)$ & $\begin{array}{l}\text { Age }-0.26^{a} \\
\text { BMI } 0.28^{a} \\
\text { Calf } 0.27^{b} \\
\text { CCG } 0.25^{a} \\
\text { Mass } 0.29^{b}\end{array}$ & Age $-0.20^{\mathrm{a}}$ & $\begin{array}{l}\text { Calf } 0.26^{b} \\
\text { CCG } 0.25^{a}\end{array}$ \\
\hline Calf girth $(\mathrm{cm})$ & $\begin{array}{l}\text { Age }-0.29^{b} \\
\text { Calf } 0.29^{b}\end{array}$ & n.s. & Age $-0.22^{\mathrm{a}}$ \\
\hline CCG $(\mathrm{cm})$ & $\begin{array}{l}\text { Age }-0.34^{b} \\
\text { BMI } 0.30^{b} \\
\text { Calf } 0.32^{b} \\
\text { Mass } 0.30^{b}\end{array}$ & n.s. & n.s. \\
\hline \multicolumn{4}{|c|}{$\begin{array}{l}\text { KEY: BMI, body mass index; BUA, broadband ultrasound attenuation; } C C G \text {, corrected calf girth; } n . s ., \text { not } \\
\text { significant. } \\
{ }^{a} p<0.05 ;{ }^{b} p<0.01 \text {. }\end{array}$} \\
\hline
\end{tabular}


TABLE 4. Group statistics of nonfallers and fallers in the previous 12 months

\begin{tabular}{|l|l|l|l|}
\hline Factor & Nonfallers $(\mathbf{N}=195)$ & Fallers $_{(\mathbf{N}=93)}$ & p value $^{\mathbf{a}}$ \\
\hline Age (years) & $76.6 \pm 5.0$ & $77.5 \pm 4.8$ & 0.18 \\
\hline Total body mass $(\mathrm{kg})$ & $62.2 \pm 10.7$ & $61.7 \pm 11.6$ & 0.71 \\
\hline Body mass index $\left(\mathrm{kg} / \mathrm{m}^{2}\right)$ & $24.3 \pm 3.8$ & $24.9 \pm 3.9$ & 0.83 \\
\hline BUA of left foot $(\mathrm{dB} / \mathrm{MHz})$ & $59.7 \pm 13.8$ & $56.3 \pm 15.7$ & 0.06 \\
\hline Hours on feet per day & $5.7 \pm 2.0$ & $5.1 \pm 2.0$ & 0.01 \\
\hline Calf girth $(\mathrm{cm})$ & $34.6 \pm 3.6$ & $33.9 \pm 3.2$ & 0.14 \\
\hline Corrected calf girth $(\mathrm{cm})$ & $29.2 \pm 2.8$ & $28.4 \pm 2.5$ & 0.02 \\
\hline${ }^{a}$ Independent $t$-tests & & \\
\hline
\end{tabular}

